\title{
Model Kasus Demam Berdarah Dengue (DBD) di Kabupaten Majalengka Tahun 2016 Berdasarkan Regresi TELBS
}

\author{
Nurul Gusriani, Firdaniza \\ Departemen Matematika FMIPA Universitas Padjadjaran \\ nurul.gusriani@unpad.ac.id, firdaniza@unpad.ac.id
}

\begin{abstract}
Abstrak
Demam Berdarah Dengue (DBD) merupakan kasus penyakit yang sudah tidak asing lagi bagi masyarakat Indonesia. Kasus ini memperoleh perhatian khusus dari pemerintah karena sering berakibat kematian karena keterlambatan penanganan. Dari segi jumlah, setiap tahunnya kasus ini selalu mengalami peningkatan, sehingga banyak dilakukan penelitian terkait dengan kasus DBD, baik dari segi usaha untuk mengurangi kasus penyakit ataupun untuk memprediksi masa yang akan datang. Paper ini akan memodelkan jumlah kasus DBD di Kabupaten Majalengka tahun 2016 dengan menggunakan regresi TELBS (Tabatabai Eby Li Bae Singh). Regresi TELBS merupakan salah satu metode regresi linier berganda untuk kasus pencilan. Keberadaan pencilan akan menyebabkan asumsi Gaussian tidak terpenuhi, sehingga jika dipaksakan dengan metode kuadrat terkecil akan menghasilkan model yang tidak baik. Regresi TELBS menghasilkan model yang dapat mewakili sebagian besar data. Hal ini ditunjukkan oleh nilai ketepatan model berdasarkan koefisien determinasi yang besar. Dengan menggunakan data sekunder dari BPS, model yang dihasilkan berdasarkan metode TELBS menunjukkan bahwa 94,7109\% jumlah kasus DBD di Kabupaten Majalengka ditentukan oleh faktor-faktor persentase angka bebas jentik nyamuk, persentase angka penduduk miskin, ketinggain daerah dari dasar dasar laut, fasilitas yang dibina dari kesehatan, kepadatan penduduk.

Kata Kunci: demam berdarah dengue, koefisien determinasi, metode kuadrat terkecil, pencilan, metode TELBS
\end{abstract}

2000 Mathematics Subject Classification: 62J05

Submit: 2021-03-19, Revisions Required:2021-05-05, Accept Submission: 2021-05-29 


\begin{abstract}
Dengue Hemorrhagic Fever (DHF) is a disease case that is familiar to Indonesian society. This case received special attention from the government because it often resulted in death due to handling. In terms of numbers, every year this case always increases, so that a lot is done related to dengue cases, both in terms of efforts to reduce words or words to predict the future. This paper will model the number of DHF cases in Kabupaten Majalengka in 2016 using the TELBS (Tabatabai Eby Li Bae Singh) regression. TELBS regression is a multiple linear regression method for outlier cases. The existence of outliers will cause the Gaussian assumption not to be fulfilled, so that if it is enforced by the Least Square method it will result in a bad model. TELBS regression produces a model that can represent most of the data. This is indicated by the value of the model accuracy based on the large coefficient of determination. Using secondary data from the BPS, model generated based on the TELBS method shows that $94.7109 \%$ of the number of DHF cases in Kabupaten Majalengka is determined by the factors of the percentage of free mosquito larvae, the percentage of the number of poor people, the elevation of the area from the seabed, the facilities that are built from health, resident population.

Keywords: dengue hemorrhagic fever, coefficient of determination, quadratic
\end{abstract} method, outlier method, TELBS method

\title{
1. Pendahuluan
}

Demam berdarah dengue (DBD) adalah penyakit demam akut yang ditemukan di daerah tropis dengan penyebaran geografis yang mirip dengan malaria. Penyakit ini disebabkan oleh salah satu dari empat serotipe virus dari genus Flavivirus, famili Flaviviridae, yang ditularkan melalui gigitan nyamuk Aedes Aegypti dan Aedes Albopictus (Anggraeni, [2]). Jumlah kasus DBD cenderung meningkat, baik dalam jumlah maupun luas wilayah yang terjangkit. Faktor utama terjadinya DBD adalah adanya virus dengue yang masuk ke dalam tubuh melalui gigitan nyamuk jenis Aedes Aegypty. Selain faktor utama, faktor DBD juga dipengaruhi oleh faktor lingkungan yang menyangkut kondisi geografis dan kondisi demografis. Kondisi geografis meliputi ketinggian wilayah dari permukaan laut, curah hujan, kelembaman, dan lain-lain. Sedangkan, kondisi demografis meliputi kepadatan penduduk, banyaknya fasiltas kesehatan, banyaknya penduduk miskin, dan lain-lain (BPS, [3]).

Pada kasus demam berdarah dengue (DBD) sangat mungkin terjadi pencilan. Hal ini dapat disebabkan oleh kondisi demografi yang ada berbeda dalam setiap lokasi. Pencilan terjadi karena ada lokasi yang mempunyai kasus DBD sangat tinggi sekali atau sebaliknya, di saat lokasi lain banyak terdapat kasus, lokasi tertentu sama sekali tidak ditemukan. Kasus demam berdarah dengue telah banyak dikaji untuk diteliti, baik dari segi usaha untuk menanggulangi penyakit maupun untuk prediksi di masa datang. Untuk segi prediksi harus diperoleh model yang baik agar hasil prediksi sedekat mungkin dengan kenyataan yang terjadi. Salah satu hal yang menyebabkan hasil prediksi tidak akurat adalah keberadaan pencilan.

Data pencilan adalah salah satu masalah dalam analisis regresi linier. Adanya pencilan dalam data akan menyebabkan garis regresi berdasarkan Metode Kuadrat Terkecil (MKT) akan tertarik ke arah pencilan tersebut. Hal ini akan menyebabkan error yang dihasilkan menjadi besar sehingga asumsi Gaussian tentang kenormalan bisa jadi tidak terpenuhi. Untuk mengatasi masalah ini, dikembangkanlah metode regresi robust yang tidak mudah dipengaruhi oleh pencilan. Beberapa metode yang robust terhadap pencilan diantaranya adalah penaksir $\mathrm{M}$ (Maximum likelihood-type estimator), penaksir MM (Methods of Moment estimator), penaksir 
LTS (Least Trimmed Square estimator), dan penaksir S (diturunkan berdasarkan Scale Statistics) (Lie \& Eby, [6]). Setiap penaksir mempunyai kelemahan atau kelebihan masing-masing. Menurut Tabatabai, et.al [13] penaksir M tidak robust terhadap leverage point. Penaksir LTS mempunyai tingkat efisiensi yang rendah akibat pemangkasan data residual pada proses estimasinya, penaksir S mempunyai tingkat efisiensi lebih tinggi dari penaksir LTS dan digunakan sebagai nilai awal pada penaksir MM (Lie \& Eby, [6]). Almetwally \& Almongy [1] melakukan perbandingan antara penaksir M, penaksir MM dan penaksir S berdasarkan nilai bias dan MSE (mean square error), dimana, sejalan dengan sampel yang semakin banyak maka MSE akan meningkat juga, dan penaksir MM merupakan penaksir yang efisien.

Metode robust lain yang ditujukan untuk mengatasi keberadaan pencilan adalah metode TELBS (Tabatabai et.al, [13]). Metode ini dapat menangani pencilan secara keseluruhan. Secara visual, garis yang dihasilkan dengan atau tanpa metode TELBS akan memperlihatkan perbedaan yang cukup besar. Kajian terkait dengan metode TELBS tidak terlalu banyak ditemukan. Gusriani, dkk [4] melakukan simulasi untuk menunjukkan garis yang dihasilkan oleh MKT dan metode TELBS memperlihatkan perbedaan yang cukup besar ketika kasus pencilan hadir. Lie \& Eby [6] melakukan perbandingan terhadap penaksir M, LTS, S, MM, dan TELBS melalui simulasi komputer. Gusriani dan Firdaniza [5] melakukan perbandingan penaksir MCD (Minumum Covariance Determinant) dengan penaksir TELBS pada data produktivitas fitoplankton.

Paper ini mengaplikasikan metode TELBS untuk memodelkan jumlah kasus demam berdarah dengue (DBD) di Kabupaten Majalengka berdasarkan faktor-faktor yang memengaruhinya. Data yang digunakan adalah data sekunder yang diperoleh dari Badan Pusat Statistik dengan unit samplingnya adalah 26 kecamatan yang berada di Kabupaten Majalengka (BPS, [3]). Dalam hal ini, jumlah kasus DBD menjadi variabel tak bebas dan faktor-faktor yang memengaruhi jumlah kasus DBD yaitu persentase angka bebas jentik nyamuk, persentase angka penduduk miskin, ketinggian daerah dari dasar dasar laut, fasilitas yang dibina dari kesehatan, dan kepadatan penduduk menjadi variabel bebas. Analisis yang dilakukan hanya menentukan model hubungan antara jumlah kasus DBD dengan faktor-faktor yang memengaruhinya, tanpa melakukan uji signifikansi terhadap parameternya.

\section{Metode Penelitian}

2.1. Analisis Regresi. Model sampel regresi linier dalam bentuk matriks dapat dinyatakan dalam persamaan

$$
y=X b+e
$$

dimana $y$ adalah vektor variabel tak bebas berukuran $(n \times 1), X$ adalah matriks variabel bebas berukuran $(n \times(p+1)), b$ adalah vektor koefisien regresi berukuran $((p+1) \times 1)$ dan $e$ adalah vektor residual $(n \times 1)$. Berdasarkan prinsip meminimalkan kuadrat residual, maka MKT akan menghasilkan taksiran untuk $b$ sebagai berikut:

$$
b=\left(X^{t} X\right)^{-1} X^{t} y
$$

Untuk melihat kecocokan model digunakan koefisien determinasi yang mencerminkan seberapa besar variasi dari variabel tak bebas $(\mathrm{Y})$ yang dapat dijelaskan oleh variabel bebas $(\mathrm{X})$. Koefisien determinasi dinyatakan dalam rumus berikut (Sembiring, [10]):

$$
R^{2}=1-\left(\frac{e^{t} e}{y^{t} y-n \bar{y}^{2}}\right)
$$

Pada model regresi tidak jarang muncul data yang berbeda dengan kebanyakan data lainnya, yang disebut dengan pencilan. Pencilan adalah pengamatan yang jauh dari pusat data, yang mungkin berpengaruh besar terhadap koefisien regresi (Sembiring, [10]). Keberadaan pencilan akan menyebabkan kesulitan dalam proses analisis data dan perlu dihindari. Adanya pencilan dapat menyebabkan error yang besar dari model, sehingga $E\left(\varepsilon_{i}\right) \neq 0$, variansi data menjadi besar, dan estimasi interval memiliki rentang yang besar, sehingga akan 
berpengaruh pada hasil pengujian parameternya. Salah satu cara untuk mendiagnosa pencilan adalah dengan matriks hat yaitu:

$$
H=X\left(X^{T} X\right)^{-1} X
$$

dimana diagonal utama dari matriks $H$ yaitu $h_{i i}$ akan menunjukkan nilai yang lebih besar dari $2 p / n$ jika data merupakan pencilan (Myers, $[8]$ ).

2.2. Metode TELBS. Keberadaan pencilan menjadi masalah jika metode klasik yaitu Metode Kuadrat Terkecil dilakukan. Kadang kala pencilan yang terjadi pada data dibuang begitu saja untuk menghasilkan model yang dapat mewakili sebagian besar data. Akan tetapi hal ini bukan merupakan ide yang bijaksana. Tidak semua pencilan diakibatkan dari kesalahan-kesalahan yang terjadi dalam pencatatan data, sehingga perlu dilakukan penyelidikan atas hal ini. Suatu cara agar tetap memperoleh model tanpa harus membuang adanya pencilan adalah dengan menggunakan metode yang robust terhadap pencilan.

Metode robust dapat menghasilkan garis regresi yang dapat mewakili sebagian besar data. Konsep robust telah berkembang pesat dalam beberapa dekade terakhir, bersamaan dengan perkembangan yang signifikan dalam alat dan teknik statistika yang kuat (Stigler, [11]). Regresi robust adalah salah satu metode yang dapat digunakan saat terdeteksi pencilan pada sekumpulan data tanpa harus menghilangkannya. Estimasi parameter dari regresi robust memberikan efisiensi 90\% sampai 95\%, sebanding dengan estimasi MKT dibawah asumsi kenormalan (Montgomery \& Elizabeth, [7]).

Salah satu metode regresi untuk mengestimasi parameter regresi ketika terdapat pencilan adalah metode TELBS yang diajukan oleh Tabatabai et.al [13]. Pada metode ini pencilan yang dimaksud meliputi pencilan dalam ruang $X$ dan ruang $Y$, sehingga metode ini dapat menangani kasus pencilan secara keseluruhan. Penaksir TELBS bekerja lebih baik jika dibandingkan dengan metode kuadrat terkecil dan metode robust lain seperti penaksir $\mathrm{M}$ dan MM (Tabatabai et.al, [13]). Garis regresi yang dihasilkan dengan metode TELBS merupakan garis yang mewakili sebagian besar data. Hasil simulasi yang dilakukan oleh Lie \& Eby [6] menunjukkan kekurangan pada penaksir M yang gagal memberikan estimasi yang baik dalam beberapa kasus, terutama ketika ukuran sampel kecil dan pencilan berada pada ruang $X$. Kegagalan ini diperbaiki oleh metode TELBS. Metode robust TELBS berkinerja baik di semua kasus yang dipertimbangkan dan mengungguli metode lain dengan keadaan persentase pencilan meningkat.

Regresi robust estimasi TELBS dilakukan dengan meminimumkan fungsi objektif (Tabatabai et.al, 2012):

$$
\min _{\beta} \sum_{i=1}^{n} \frac{\rho\left(t_{i}\right)}{L_{i}}=\min _{\beta} \sum_{i=1}^{n} \frac{1-\operatorname{sech}\left(\omega t_{i}\right)}{L_{i}}
$$

Berdasarkan Tabatabai

textitet.al [13], fungsi $\rho$ adalah fungsi diferensiabel dan $\omega$ adalah bilangan real positif yang disebut sebagai konstanta kesesuaian (tunning constant) yang bernilai 0,628 . Nilai $\omega=0,628$ menyebabkan metode TELBS mempunyai tingkat efisiensi yang cukup tinggi (Lie \& Eby, [6]).

Merujuk persamaan (5),

$$
\begin{gathered}
t_{i}=\frac{\left(y_{i}-x_{i}^{t} b\right)\left(1-h_{i i}\right)}{\hat{\sigma}} \\
L_{i}=\sum_{j=1}^{p} \max \left(M_{j},\left|x_{i j}\right|\right) \\
M_{j}=\operatorname{median}_{\{}\left\{\left|x_{1 j}\right|,\left|x_{2 j}\right|, \ldots,\left|x_{n j}\right|\right\} \\
\hat{\sigma}=1.192 \operatorname{median}_{i ; 1 \leq i \leq n}\left(\operatorname{median}_{j ; 1 \leq j \leq n}\left|e_{i}-e_{j}\right|\right)
\end{gathered}
$$

Nilai 1,1926 ditujukan agar $\hat{\sigma}$ menjadi estimasi yang mendekati tak bias dari sampel yang terbatas (Rousseeuw \& Croux, [9]). Untuk meminimumkan persamaan (5), ditentukan 
turunan dari $\rho$ terhadap $b_{0}$ dan $b_{j},(j=1,2,, p)$ kemudian disamakan dengan nol, sehingga menghasilkan persamaan:

$$
\sum_{i=1}^{n} \frac{\psi\left(t_{i}\right)}{L_{i}} \frac{\left(1-h_{i i}\right)}{\hat{\sigma}} \frac{\partial\left(y_{i}-b_{0}-x_{i 1} b_{1}-\cdots-x_{i k} b_{k}\right)}{\partial b_{j}}=0
$$

dengan $\psi(x)=\frac{\partial \rho(x)}{\partial x}=\omega \operatorname{sech}(\omega x) \tanh (\omega x)$. Didefinisikan fungsi pembobot $w_{i i}$ adalah (Stigler, [11]):

$$
w_{i i}=\frac{\psi\left(t_{i}\right)\left(1-h_{i i}\right)}{\hat{\sigma} e_{i} L_{i}}
$$

Setelah bobot $w_{i i}$ diperoleh, kemudian dapat dibentuk matriks $W$ yang berukuran $n x n$ yaitu $W=\left[\begin{array}{cccc}W_{11} & W_{12} & \ldots & W_{1 n} \\ W_{21} & W_{22} & \ldots & W_{2 n} \\ \vdots & \vdots & \ddots & \vdots \\ W_{n 1} & W_{2 n} & \ldots & W_{n n}\end{array}\right]$ dengan elemen diagonalnya adalah $w_{i i}$, dan entri matriks $w_{i j}=0 ;(i \neq 0)$. Persamaan (10) kemudian dapat ditulis menjadi:

$$
\sum_{i=1}^{n} w_{i i} e_{i} \frac{\partial\left(y_{i}-b_{0}-x_{i 1} b_{1}-\cdots-x_{i k} b_{k}\right)}{\partial b_{j}}=0
$$

Setelah terbentuk matriks $\mathrm{W}$, maka parameter taksiran $b_{T E L B S}$ diperoleh dengan cara sebagai berikut:

$$
b_{T E L B S}=\left(X^{t} W X\right)^{-1} X^{t} W y
$$

Pada metode TELBS nilai $b$ diperoleh dengan melakukan prosedur iterasi sampai kekonvergenan tercapai.

Selanjutnya koefisien determinasi pada analisis regresi robust dengan metode estimasi TELBS dapat ditentukan dengan persamaan berikut (Tabatabai et.al, [13]):

$$
R^{2}=1-\left(\frac{\operatorname{Median}_{i: 1 \leq i \leq n}\left|e_{i}\right|}{\operatorname{Median}_{i: 1 \leq i \leq n}\left|y_{i}-\operatorname{Median}_{i: 1 \leq i \leq n} \hat{y}_{i}\right|}\right)^{2}
$$

2.3. Data dan Prosedur Analisis. Data yang digunakan dalam penelitian ini adalah data sekunder yang diperoleh dari Dinas Kesehatan dan web resmi Badan Pusat Statistika (BPS) di Kabupaten Majalengka pada tahun 2016 (BPS, [3]). Kabupaten Majalengkan terdiri dari 26 kecamatan dengan luas daerah 1204,24km2 atau sekitar 2,71\% dari luas Propinsi Jawa Barat dan jumlah penduduk sekitar 1.169.337 jiwa. Kecamatan-kecamatan tersebut adalah kecamatan Lemah Sugih, Bantarujeg, Malausma, Cikijing, Cingambul, Talaga, Banjaran, Argapura, Maja, Majalengka, Cigasong, Sukahaji, Sindang, Rajagaluh, Sindangwangi, Leuwimunding, Palasah, Jatiwangi, Dawuan, Kasokandel, Panyingkiran, Kadipaten, Kertajati, Jatitujuh, Ligung, dan Sumberjaya.

Variabel yang digunakan pada penelitian ini adalah jumlah kasus DBD di tiap kecamatan $(Y)$, persentase angka bebas jentik nyamuk $\left(X_{1}\right)$, persentase angka penduduk miskin $\left(X_{2}\right)$, ketinggian daerah dari dasar dasar laut $\left(X_{3}\right)$, fasilitas yang dibina dari kesehatan $\left(X_{4}\right)$, dan kepadatan penduduk $\left(X_{5}\right)$. Berikut algoritma yang disusun untuk memudahkan perhitungan pada metode TELBS:

Pada Gambar 1 terlihat bahwa analisis pada metode TELBS dilakukan melalui iterasi dengan mengambil nilai inisial yang diperoleh dari MKT. Proses iterasi akan berhenti ketika kekonvergenan tercapai yaitu $10^{-5}$.

\section{Hasil Analisis}

Data sekunder mengenai jumlah kasus DBD yang diperoleh dari web resmi Badan Pusat Statistika (BPS) di Kabupaten Majalengka pada tahun 2016 (BPS, [3]) menunjukkan diagram berikut: 


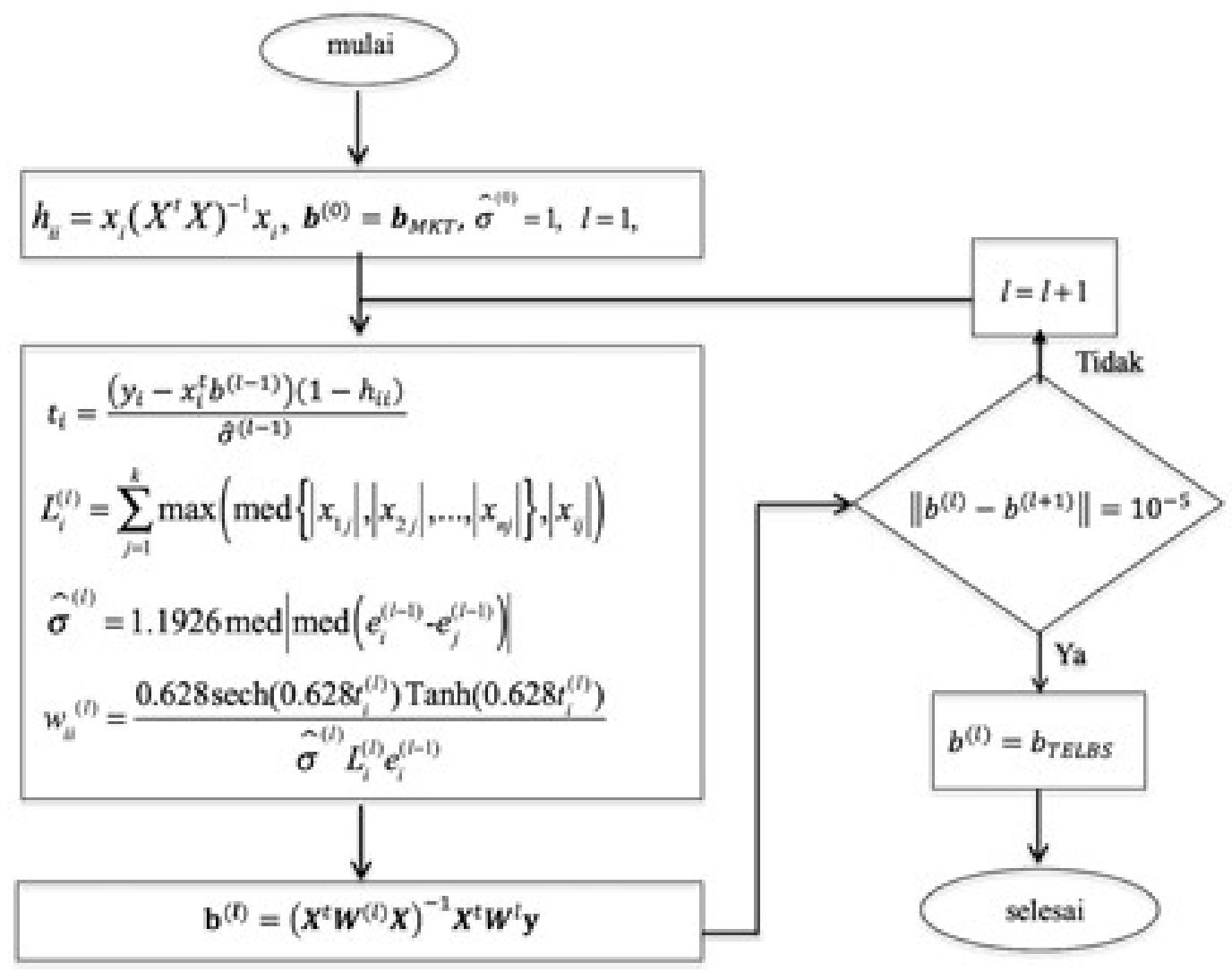

Gambar 1. Algoritma Metode TELBS

Jumlah Kasus DBD Kabupaten Majalengka 2016

- Lemah sugih

- Malausma

- Cingambul

- Banjaran

- Maja

- Cigasong

- Sindang

- Sindangwangi

- Palasah

- Dawuan

- Panyingkiran

- Kertajati

- Ligung
- Bantarujeg

- Cikijing

- Talaga

- Argapura

- Majalengka

- Sukahaji

- Rajagaluh

- Leuwimunding

- Jatiwangi

- Kasokandel

- Kadipaten

- Jatitujuh

- Sumberjaya

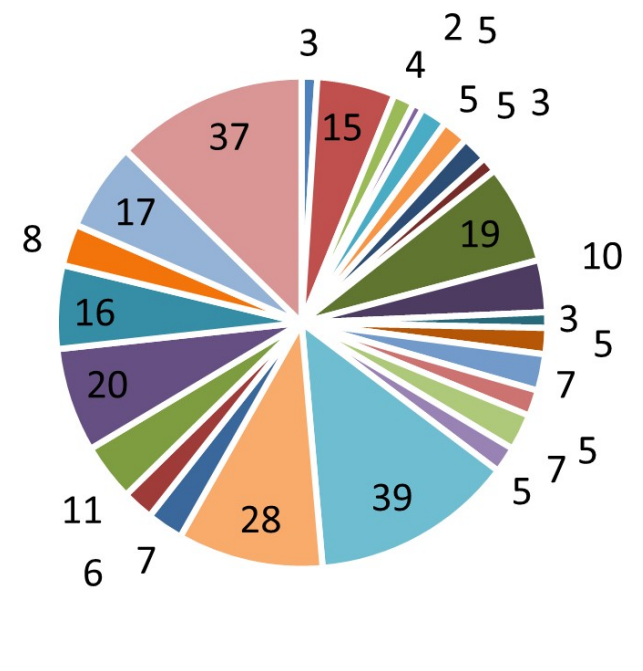

GAmBAR 2. Diagram Lingkaran Jumlah Kasus DBD Kabupaten Majalengka 2016 
Dari Gambar 2 terlihat untuk Kecamatan Palasah, Jatiwangi dan Sumberjaya terjadi kasus DBD yang cukup tinggi dibandingkan dengan kecamatan-kecamatan lainnya. Secara rata-rata kasus DBD di Kabupaten Majalengka selama setahun adalah 11,23077 kasus di setiap kecamatannya dengan median 7 dan standar deviasi sebesar 10,17962.

Diagram boxplot dari data kasus DBD di Majalengka ditunjukkan pada Gambar 3.

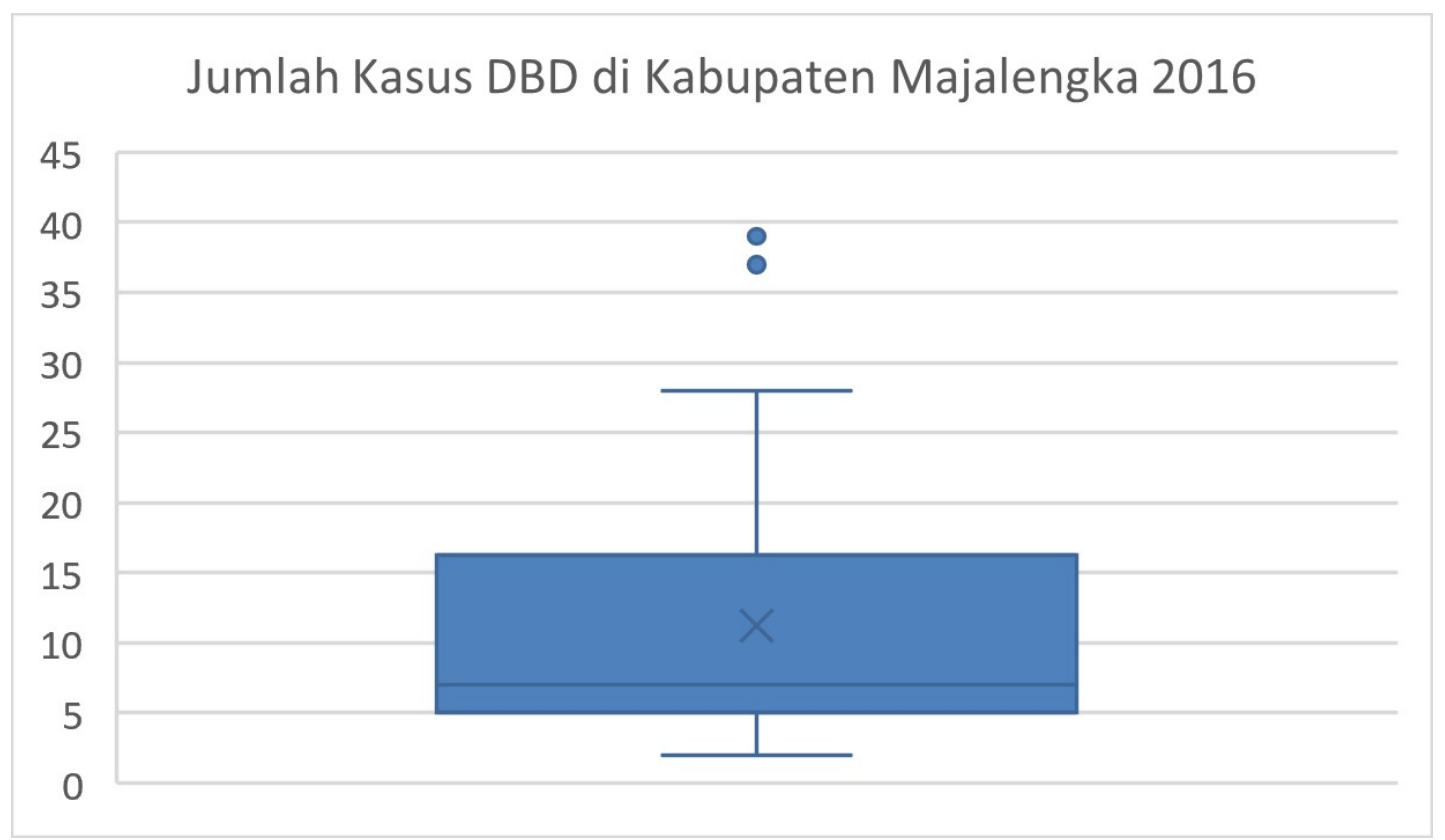

Gambar 3. Diagram Boxplot Jumlah Kasus DBD Kabupaten Majalengka 2016

Dari Gambar 3 terlihat bahwa posisi median lebih mendekati kuartil pertama, sehingga pola data tersebut mencirikan sebaran dengan kemiringan positif. Dua buah titik di luar batas pagar menunjukkan bahwa terdapat kecamatan yang jumlah kasus DBD lebih banyak dibandingkan dengan kecamatan-kecamatan lainnya. Hasil boxplot di atas, yang didasarkan hanya pada data variabel tak bebas saja, memperlihatkan kemungkinan terjadinya pencilan. Apabila data secara lengkap yang melibatkan variabel bebas dan tak bebas dianalisis dengan menggunakan Metode Kuadrat Terkecil, akan menghasilkan taksiran untuk parameter-parameter model seperti yang dinyatakan pada Tabel 1.

TABel 1. Koefisien Regresi dan Determinasi dengan Metode Kuadrat Terkecil

\begin{tabular}{|c|c|}
\hline Koefisien & Nilai \\
\hline$b_{0}$ & 0,83558240 \\
\hline$b_{1}$ & 1,07574219 \\
\hline$b_{2}$ & 0,03655638 \\
\hline$b_{3}$ & $-0,00158411$ \\
\hline$b_{4}$ & 0,032833848 \\
\hline$b_{5}$ & $-0,00095261$ \\
\hline$R^{2}$ & 0,59538302 \\
\hline
\end{tabular}

Tabel 1 memperlihatkan nilai koefisien intersep, nilai koefisien regresi berdasarkan variabelvariabel bebas yang berpengaruh terhadap varibel tak bebas, dan nilai koefisien determinasi. Koefisien determinasi pada Tabel 1 belum menghasilkan model yang baik. Sugiyono [12] menyatakan bahwa nilai koefisien determinasi yang berkisar 0,4-0,599 menunjukkan model dengan 
tingkat hubungan sedang. Berdasarkan arti dari koefisien determinasi, pada data penelitian ini hanya 59,54\% jumlah kasus DBD di Majalengka disebabkan oleh oleh faktor-faktor persentase angka bebas jentik nyamuk, persentase angka penduduk miskin, ketinggian daerah dari dasar laut, fasilitas yang dibina dari kesehatan, kepadatan pendududuk, sisanya ditentukan oleh faktor lain yang tidak masuk dalam model. Berangkat dari hal tersebut, hasil deskriptif awal mengenai boxplot pada variabel bebas yang menunjukkan adanya pencilan, menjadi semakin kuat. Untuk itu perlu dilakukan analisis lebih lanjut berkaitan dengan pencilan.

Untuk mengetahui keberadaan pencilan pada data, langkah selanjutnya adalah melakukan pendeteksian menggunakan matriks hat dengan hasil sebagai berikut:

TABEL 2. Nilai Diagonal Utama pada Matriks Hat

\begin{tabular}{|c|c|c|c|}
\hline No & $h_{i i}$ & No & $h_{i i}$ \\
\hline 1 & 0.3198 & 14 & 0.0904 \\
\hline 2 & 0.1034 & 15 & 0.0952 \\
\hline 3 & 0.1742 & 16 & 0.3384 \\
\hline 4 & 0.1659 & 17 & 0.2268 \\
\hline 5 & 0.3266 & 18 & 0.2837 \\
\hline 6 & 0.1562 & 19 & 0.2560 \\
\hline 7 & 0.1322 & 20 & 0.1795 \\
\hline 8 & 0.2956 & 21 & 0.2535 \\
\hline 9 & 0.2679 & 22 & 0.3992 \\
\hline 10 & 0.3704 & 23 & 0.3607 \\
\hline 11 & 0.1803 & 24 & 0.2464 \\
\hline 12 & 0.0760 & 25 & 0.2366 \\
\hline 13 & 0.2463 & 26 & 0.2188 \\
\hline
\end{tabular}

Pada Tabel 2 diperoleh satu pencilan yang terjadi yaitu data ke-22 dengan nilai $h_{i i} 0,3992$ yang nilainya lebih besar dari batas pencilan bagi matriks hat yaitu $2(5 / 26)=0,385$. Walaupun hanya satu data yang terkonfirmasi sebagai pencilan, hal ini tetap akan berpengaruh pada model yang dihasilkan. Model yang terbentuk dengan MKT menjadi model yang tidak baik, oleh karen itu analisis selanjutnya adalah dengan metode TELBS. Nilai koefisien regresi yang diperoleh pada MKT (Tabel 1) digunakan sebagai nilai inisial pada iterasi awal. Dengan bantuan software Maple analisis dilakukan mengikuti algoritma pada Gambar 1 dan mencapai kekonvergenan pada iterasi ke-20. Berikut tabel hasil pengolahan dengan menggunakan metode TELBS.

Tabel 2 menunjukkan bahwa model regresi linear dengan nilai koefisien regresi berdasarkan metode TELBS menghasilkan nilai koefisien determinasi yang jauh berbeda dibandingkan dengan MKT. Koefisien determinasi berdasarkan metode TELBS, menunjukkan bahwa 94,71\% jumlah kasus DBD di Majalengka ditentukan oleh faktor-faktor persentase angka bebas jentik nyamuk, persentase angka penduduk miskin, ketinggian daerah dari dasar laut, fasilitas yang dibina dari kesehatan, kepadatan pendududuk, sisanya yaitu sebesar 5,29\% ditentukan oleh faktor lain yang tidak masuk ke dalam penelitian. Nilai koefisien determinasi ini menunjukkan bahwa model yang dihasilkan dengan metode TELBS lebih baik dibandingkan dengan model MKT ketika kasus pencilan hadir. 
TABel 3. Koefisien Regresi dan Determinasi dengan Metode TELBS

\begin{tabular}{|c|c|}
\hline Koefisien & Nilai \\
\hline$b_{0}$ & 8,99830261 \\
\hline$b_{1}$ & 0,83522169 \\
\hline$b_{2}$ & 0,14465909 \\
\hline$b_{3}$ & $-0,00341391$ \\
\hline$b_{4}$ & $-0,101440361$ \\
\hline$b_{5}$ & $-0,001177396$ \\
\hline$R^{2}$ & 0,94710926 \\
\hline
\end{tabular}

\section{Simpulan}

Dari hasil analisis yang telah dilakukan, pada data terdapat pencilan yang ditunjukkan dengan nilai diagonal utama pada matriks hat yang melebihi batas yang ditentukan. Berdasarkan hal tersebut, untuk memodelkan kasus demam berdarah di Kabupaten Majalengka tahun 2016 dilakukan dengan menggunakan metode TELBS dengan hasil berikut:

$$
\hat{y}_{i}=0,8998+0,8352 x_{i 1}+0,1447 x_{i 2}-0,0034 x_{i 3}-0,1014 x_{i 4}-0,0012 x_{i 5} .
$$

Model di atas memiliki nilai koefisien determinasi yang cukup tinggi, dengan demikian dapat disimpulkan bahwa pemodelan kasus demam berdarah di Kabupaten Majalengka tahun 2016 dengan menggunakan metode TELBS menghasilkan model yang lebih baik. Nilai koefisien yang diperoleh menunjukkan bahwa 94,71\% jumlah kasus DBD di Majalengka ditentukan oleh faktor-faktor persentase angka bebas jentik nyamuk, persentase angka penduduk miskin, ketinggian daerah dari dasar laut, fasilitas yang dibina dari kesehatan, kepadatan pendududuk, sisanya yaitu sebesar 5,29\% ditentukan oleh faktor lain yang tidak masuk ke dalam penelitian.

\section{Ucapan Terimakasih.}

Penelitian ini didanai oleh Hibah Internal Universitas Padjadjaran 2017 dengan Nomor Kontrak 872/UN6.3.1/LT/2017 dengan judul Menentukan Tingkat Kemiskinan di Jawa Barat Menggunakan Regresi TELBS.

\section{DAFTAR Pustaka}

[1] Almetwally, E.M \& Almongy, H.M., 2018, Comparison between M-Estimation, S-Estimation, and MM Estimation Methodes of Robust Estimation with Application and Simulation,International Journal of Mathematical Archive, Volume 9 No. 11.

[2] Anggraeni, 2010, Stop Demam Berdarah Dengue, Bogor: Cita Insan Madani.

[3] Badan Pusat Statistika, 2016, Majalengka dalam Angka 2016, Majalengka: BPS Kabupaten Majalengka/BPS-Statistic of Majalengka Regency.

[4] Gusriani, N., Firdaniza, Oktaviani, N., 2017, Regresi TELBS untuk Mengatasi Masalah Pencilan, Proceeding $8^{\text {th }}$ Industrial Research Workshop and National Seminar Politeknik Negeri Bandung July 26-27.

[5] Gusriani, N \& Firdaniza, 2018, Linear Regression Based on Minimum Covariance Determinant (MCD) and TELBS Methods on The Productivity of Phitoplankton IOP Conference Series: Material Science and Engineering, Volume 332, Issue 1.

[6] Lie, H. \& Eby, W.M., 2018, A Comparative Study of TELBS Robust Linear Regression, American Review of Mathematics and Statistics.

[7] Montgomery, D.C., \& Elizabeth, P.A., 1992, Introduction To Linier Regression Analysis. Canada: John Willey \& son,Inc.

[8] Myers, R.H, 1990, Classical and Modern Regression with Applications, 2nd edition. Boston, PSW-KENT Publishing Company. 
[9] Rousseeuw, P.J and Croux, 1993, Alternative to the Median Absolute Deviation, American Statistical Association, Volume 88, No. 424.

[10] Sembiring, R.K., 2003, Analisis Regresi, Edisi 2. Bandung: ITB.

[11] Stigler, S. M., 2010, The changing history of robustness. The American Statistician, Volume 64, No. 4.

[12] Sugiyono, 2014, Metode Penelitian Bisnis, Edisi Kedelapan belas, Bandung: Alfabeta.

[13] Tabatabai, M.A., Eby, M.M., Li, H., Bae, S., and Singh, K.P., 2012, TELBS Robust Linear Regression Method, Open Acces Medical Statistics, USA, Dove Medical Press. 